\title{
Low Self-esteem and its Relation with Psychological Distress among Dental Students
}

\author{
Ali Sabri Radeef and Ghasak Ghazi Faisal
}

\begin{abstract}
Since self-esteem has been recognized to predict health and psychological well-being, it is crucial to assess the self-esteem and its relation with psychological distress. Methodology: This study was conducted among 257 dental students. The psychological distress was assessed using the 12item General Health Questionnaire (GHQ-12) while self-esteem was assessed using the adult form of the Coopersmith SelfEsteem Inventory. Results: Female students had significantly lower self-esteem compared to male students (51.4 and 59.1 respectively). There is a strong negative correlation between psychological distress and self-esteem $(r=-0.5, p<0.00)$. Students with psychological distress had significantly lower mean self-esteem score compared to those who are not distressed (43.07 and 60.03 respectively). Conclusion: Low selfesteem is higher among female students and self-esteem is negatively correlated to psychological distress among undergraduate students.
\end{abstract}

Index Terms - Self-esteem, dental, students, psychological distress.

\section{INTRODUCTION}

Currently mental health has become one of the most critical issues among individuals of all ages. Mental health is vital for students in order to be able to function well socially and academically. Undergraduate students are more prone to mental illness as they are going through change from teenagers to adults [1].

It is a crucial need to have good self-esteem for sustainability of health psychological development. It helps the person to deal better with the stressors. It has a major role in development of personality. Self-esteem reflects how an individual perceives self-significance and worth [2],[3].

Psychological distress is a general term used to describe the state of impaired psychological health which consists of a combination of symptoms extending from depression and anxiety to personality traits, functional disabilities and behavioural problems [4],[5].

Studies in Malaysia have investigated the impact of stressors on students' mental health as being an undergraduate student imposes multiple stressful factors such as living in a hostel away from their family, adapting to the curriculum and academic achievement which they need to cope with. When these stressors are prolonged and sever

Published on May 17, 2019.

Ali Sabri Radeef is with the Department of Psychiatry, Kulliyyah (Faculty) of Medicine, International Islamic University Malaysia.

Ghasak Ghazi Faisal is with the Department of Fundamental dental and Medical Sciences, Kulliyyah (Faculty) of Dentistry, International Islamic University Malaysia.

Corresponding Author: Ghasak Ghazi Faisal

(e-mail: drghassak@yahoo.com) it may precipitate psychological distress and emotional disturbances including depression, anxiety and stress [6],[7],[8],[9],[10]. Therefore, this study aimed to determine the prevalence of psychological distress among dental undergraduate students.

Though low self-esteem does not be considered as a standalone mental illness, there are strong associations connecting perceiving oneself as worthy individual, ability to recognize own good qualities with psychological and emotional well-being.

Since self-esteem has been recognized to predict health and psychological well-being, it is crucial to assess the selfesteem and its relation with psychological wellbeing which may help in improving student mental health to enhance the students' learning capabilities and their quality of life.

\section{Methodology}

A cross sectional prospective study conducted among 257 dental students from Kulliyyah of Dentistry, International Islamic University Malaysia (IIUM) in 2017. Students voluntarily participated in this study, verbal consent was obtained. The 12-item General Health Questionnaire (GHQ12) was used to determine the rate of psychological distress among dental undergraduate students. The items on the GHQ- 12 represent 12 manifestations of psychological distress, and respondents were asked to rate the presence of each of these manifestations in themselves during the last few weeks preceding the study period. A binary scoring method is used to evaluate responses (i.e. 0-0-1-1). Thus, responses can only be scored as zero or one. The minimum GHQ-12 total score was 0 and the maximum GHQ-12 total score was 12 'Caseness' was defined as a total questionnaire score of 4 or more [11],[12].

Self-esteem was assessed using the adult form of the Coopersmith Self-Esteem Inventory [13].

The socio-demographic information including: Nationality and race, age, marital status, religion, gender, year of study, accommodation during study, and other variables were obtained.

\section{Statistical Analysis:}

Statistical package for social science program, version 22.0 (SPSS 22.0) was used for data analysis. The sociodempgraphic variables were presented in numbers and percentages. The univariate association between gender of students and psychological distress was determined using Chi-square.

Then, $\mathrm{t}$ - test was used to determine the effects of the gender, psychological distress and phase of study on the self-esteem among the students. The relationship between psychological distress and self-esteem was evaluated using 
Pearson correlation. $\mathrm{P}$ values less than 0.05 was considered statistically significant

\section{RESULTS}

A total of 257 out of 290 (88\%) dental students participated in this study. Regarding the distribution of students; 56, 42, 51, 54, and 54 students participated from year1, year2, year3, year4, and year5 respectively. The majority of the students were females, aged above 21 years, Malaysian, single, living in the hostel with monthly household income ranged (>5000 Ringgit Malaysia). In this study, $40.1 \%$ of dental students were found to be psychologically distressed. The rate was found to be significantly higher in female than male students, 43.7 and $\% 28.2 \%$, respectively $(\mathrm{P}<0.05)$. (Table I)

TABLE I: Psychological distress among male and females Students.

\begin{tabular}{|c|c|c|c|c|c|c|}
\hline \multirow{2}{*}{} & \multirow{2}{*}{\begin{tabular}{c} 
Total \\
\cline { 3 - 6 }
\end{tabular}} & \multicolumn{2}{|c|}{ Yes } & \multicolumn{2}{|c|}{ NO } & \multirow{2}{*}{ P value } \\
\cline { 3 - 6 } & No. & No. & $\%$ & No. & \% & \multirow{2}{*}{ \% valogical Distress } \\
\hline Gender & & & & & & \multirow{2}{*}{$\mathbf{0 . 0 2 8}$} \\
\hline Male & 59 & 17 & 28.8 & 42 & 71.2 & \\
\hline Female & 197 & 86 & 43.7 & 111 & 56.3 & \\
\hline Total & 257 & 103 & 40.1 & 154 & 59.9 & \\
\hline
\end{tabular}

Students with psychological distressed have significantly lower mean self-esteem score compared to those who are not distressed (43.07 and 60.03 respectively; $\mathrm{P}<0.05$ ). Low self-esteem is significantly higher among female than male students (51.4 and 59.1 respectively; $\mathrm{P}<0.05$ ). (Table II)

\begin{tabular}{|c|c|c|c|c|}
\hline 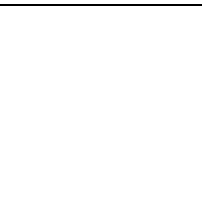 & $\begin{array}{l}\text { No. } \\
(\%)\end{array}$ & $\begin{array}{c}\text { Self- } \\
\text { esteem } \\
\text { Mean } \\
\text { Score }\end{array}$ & $\begin{array}{c}\text { Std. } \\
\text { Deviation }\end{array}$ & $\begin{array}{c}\text { P- } \\
\text { Value }\end{array}$ \\
\hline Gender & & & & \multirow{3}{*}{0.006} \\
\hline Male & $\begin{array}{c}60 \\
(23.3)\end{array}$ & 59.1 & 19.4 & \\
\hline Female & $\begin{array}{c}197 \\
(76.7)\end{array}$ & 51.4 & 18.5 & \\
\hline \multicolumn{4}{|l|}{$\begin{array}{c}\text { Psychological } \\
\text { distress }\end{array}$} & \multirow{3}{*}{0.000} \\
\hline Negative & $\begin{array}{c}154 \\
(59.9)\end{array}$ & 60.03 & 16.834 & \\
\hline Positive & $\begin{array}{c}103 \\
(40.1)\end{array}$ & 43.07 & 17.417 & \\
\hline \multicolumn{4}{|l|}{ Phase of study } & \multirow{3}{*}{0.91} \\
\hline Pre-clinical & 98 & 53.06 & 18.965 & \\
\hline Clinical & 159 & 53.33 & 19.020 & \\
\hline
\end{tabular}

There was a strong negative correlation between psychological distress and self-esteem $(r=-0.54, p<0.00)$.

(Table III) TABLE III: correlation between psychological distress and self-esteem.

\begin{tabular}{|c|c|c|c|c|}
\hline \multicolumn{5}{|c|}{ Correlations } \\
\hline & & & $\begin{array}{l}\text { Self- } \\
\text { estee } \\
\text { m }\end{array}$ & $\begin{array}{c}\text { Psyc } \\
\text { holo } \\
\text { gical } \\
\text { distr } \\
\text { ess }\end{array}$ \\
\hline \multirow{6}{*}{$\begin{array}{l}\text { Spear } \\
\text { man's } \\
\text { rho }\end{array}$} & \multirow[t]{3}{*}{$\begin{array}{l}\text { Self- } \\
\text { esteem }\end{array}$} & $\begin{array}{l}\text { Correlation } \\
\text { Coefficient }\end{array}$ & 1.000 & $-0.5^{\star *}$ \\
\hline & & $\begin{array}{l}\text { Sig. (2- } \\
\text { tailed) }\end{array}$ & . & .000 \\
\hline & & $\mathrm{N}$ & 257 & 257 \\
\hline & \multirow{3}{*}{$\begin{array}{l}\text { Psycho } \\
\text { logical } \\
\text { distress }\end{array}$} & $\begin{array}{l}\text { Correlation } \\
\text { Coefficient }\end{array}$ & $-.0 .5^{\star *}$ & 1.000 \\
\hline & & $\begin{array}{l}\text { Sig. (2- } \\
\text { tailed) }\end{array}$ & .000 & . \\
\hline & & $\mathrm{N}$ & 257 & 257 \\
\hline
\end{tabular}

\section{DISCUSSION}

In this study, the rate of psychological distress among students was $41.1 \%$ which is higher than other studies in Malaysia in which the rate was found to be $29.6 \%, 30.1 \%$ and 38.8 respectively[6],[14].

These differences in rates may be due to different courses or number of participants recruited or due to different assessment tools used or the cut off score used to indicate caseness

In this study psychological distress was significantly associated with female students. This result was similar to previous studies among college students [6],[7],[10]. One study in Malaysia revealed that the rate of psychological distress is slightly higher among female students, but it was not statistically significant [15], while another Malaysian study stated that no differences were observed between the genders [16],[17]. The reasons for the difference in gender can be hypothesised to involve hormonal differences, differing psychosocial stressors for women and men, and behavioural models of learned helplessness.

There was no significant association between phase of study and both self-esteem and psychological distress which was similar to previous study in which was no significant difference in the prevalence of psychological distress according to the phase of the study [18].

Low self-esteem is significantly higher among female than male students which compactable with finding in a previous study [19]. 
A strong negative correlation between psychological distress and self-esteem was found in this study and students with psychological distressed have significantly lower mean self-esteem score compared to those who are not distressed which was compactable with previous studies among undergraduate students [20],[21].

A study among college students revealed that feeling of incompetence and inadequacy and low self-esteem can predict high psychological distress [22].

The relationship between low self-esteem and psychological distress can be considered as a vicious cycle as one can lead to the other and it is difficult to say which one comes first. When there is a combination of both of them, the impact on mental health is expected be more hazardous and critical since both of them are known to predispose and precipitate etiological factors for mental illness. Furthermore, those individuals with low self-esteem who are already diagnosed with mental illness may attribute low self-esteem to the social stigma of mental illness which leads to negative feelings towards themselves and a feeling that they are not worth to be loved, be happy or successful.

The result of this study may aid in designing appropriate intervention strategies for early detection of and intervention for both psychological distress and low self-esteem such as building self-esteem to enhance the students' learning abilities and their lifestyles.

\section{CONCLUSION}

Low self-esteem is associated with psychological distress among undergraduate students. To warrant better academic achievement and enhance mental health of the students, it is crucial to highlight the importance of early assessment and identification of both low self-esteem and psychological distress followed by building self-esteem and proper and early psychological intervention,

\section{ACKNOWLEDGMENT}

We would like to express our appreciation to all the dental students for their participation and consent. Also to International Islamic University Malaysia for funding this project (Grant number P-RIGS-18-030-0030).

\section{REFERENCES}

[1] Giugliano RJ, "The systemic neglect of New York's young adults with mental illness," Psychiatric services, vol. 55(4),pp.451-453, 2004.

[2] Ali SM, Malik AA, "Psychopathology and self esteem among students of University of Karachi," International Journal of Innovation and Scientific Research, vol.10(2),pp.387-94, 2014.

[3] Parthi K, Rohilla SS, "A Study of Mental Health, Perceived Stress, and Self-Esteem among Students in Higher Education," The International Journal of Indian Psychology, vol.4 (4), 2017.

[4] Aline Drapeau, Alain Marchand, Dominic Beaulieu-Prévost, "Epidemiology of Psychological Distress, Mental Illnesses Understanding, Prediction and Control," Prof. Luciano LAbate (Ed.), ISBN: 978-953-307-6621, InTech, 5: 105-134. 2012.

[5] Mirowsky, J., C.E. Ross, "Selecting outcomes for the sociology of mental health: Issues of measurement and dimensionality," Journal of Health and Social Behavior, vol. 43, pp.152-170, 2002.

[6] Radeef AS, Faisal GG, "Psychological Distress and Sources of Stressors amongst Medical and Science Undergraduate Students in Malaysia," Makara Journal of Health Research,vol.8, pp.61-7, 2017.
[7] Radeef AS, Faisal GG, "Depression, anxiety and stress with possible sources of stressors among undergraduate medical students in Malaysia," Brunei International Medical Journal,vol. 12 (1),pp. 18-25, 2016.

[8] Shamsuddin K, Fariza F, Wan Salwina WI, et al, "Correlates of depression, anxiety and stress among Malaysian university students," Asian Journal of Psychiatry, vol. 6 pp.318-23, 2013.

[9] Azlina Wati Nikmat, "Psychological well-being, stress and coping style among pre-clinical medical students" Research management institute, Universiti Teknologi Mara. 2010.

[10] Radeef AS, Faisal GG, Ali SM, Mohamed Ismail MKH, "Source of stressors and emotional disturbances among undergraduate science students in Malaysia," International Journal of Medical Research and Health Science, vol. 3pp.401-0, 2014.

[11] Goldberg, D. P.,Williams, P, A user's guide to the General Health Questionnaire. Windsor UK: NFER-Nelson. 1988.

[12] Goldberg, D. P., Gater, R., Sartorius, N., Ustun, T. B., Piccinelli, M., Gureje, O. \& Rutter, C. "The validity of two versions of the GHQ in the WHO study of mental illness in general health care," Psychological Medicine, vol. 27(1), pp.191-197, 1997.

[13] Coopersmith, S. "The antecedents of self-esteem". San Francisco: W. H. Freeman \&Co.1967.

[14] Yusoff MS, Abdul Rahim AF, Yaacob MJ, "Prevalence and Sources of Stress among Universiti Sains Malaysia Medical Students". Malaysia Journal of Medical Science., 17(1),pp.30-7, 2010

[15] Sherina MS, Rampal L, Kaneson, "Psychological stress among undergraduate medical student" Medical Journal Malaysia, 59, pp.207-11, 2004.

[16] Zulkefly NS, Baharudin R, "Using the 12-item General Health Questionnaire (GHQ-12) to assess the psychological health of Malaysian college students" Global Journal of Health Science,2, pp73, 2010.

[17] Firth J, "Levels and sources of stress in medical students" Brunie Medical Journal, 292, pp.1177-80, 2010.

[18] Sreeramareddy CT, Shankar PR, Binu VS, Mukhopadhyay C, Ray B, Menezes RG. Psychological morbidity, sources of stress and coping "strategies among undergraduate medical students of Nepal" BMC Medical Education, 7:1, 2007.

[19] Arshad M, Zaidi SM, Mahmood K, "Self-Esteem \& Academic Performance among University Students" Journal of Education and Practice, 6 (1), pp.156-62, 2015.

[20] [20] Harikrishnan U, Ali A, "Resilience, Psychological Distress, and Self-Esteem among Undergraduate Students in Kollam District, Kerala" Journal of Social Work Education and Practice, 3(4), pp.27-36, 2018.

[21] Papazisis G, Nicolaou P, Tsiga E, Christoforou T, SapountziKrepia D, "Religious and spiritual beliefs, self-esteem, anxiety, and depression among nursing students" Nursing \& health sciences, 16(2), pp.232-8,2014.

[22] Peteet BJ, Brown CM, Lige QM, Lanaway DA, "Impostorism is associated with greater psychological distress and lower selfesteem for African American students" Current Psychology,34(1) pp.154-63, 2015. 
